\title{
Surrogate Climate Change Scenario and Projections with a Regional Climate Model: Impact on the Aridity in South America
}

\author{
Sergio H. Franchito, Julio P. Reyes Fernandez, David Pareja \\ Centro de Previsão de Tempo e Estudos Climáticos, CPTEC, Instituto Nacional de Pesquisas Espaciais, INPE C.P. \\ 515, 12201-970, São José dos Campos, Brazil \\ Email: sergio.franchito@cptec.inpe.br
}

Received 2 September 2014; revised 2 October 2014; accepted 17 October 2014

Copyright (C) 2014 by authors and Scientific Research Publishing Inc.

This work is licensed under the Creative Commons Attribution International License (CC BY). http://creativecommons.org/licenses/by/4.0/

\section{(c) (i) Open Access}

\section{Abstract}

The impact of global warming on the aridity in South America (SA) is investigated. For this purpose, the methodology for generating surrogate climate-change scenarios with a RCM is employed. For the present climate (CTRL) the RCM is initialized with and driven by ECMWF/ERA-Interim reanalysis data. Two aridity indices are used: the Budyko and the UNEP indices. The results for the CTR are in agreement with other model studies which indicate future warming; rainfall increases in southeastern South America, Ecuador and Peru and decreases in the central and eastern Amazon. In general the model reproduces the aridity in the continent compared with the observed data for both indices. The distribution of aridity over SA in surrogate climate-change scenario shows an increase of the dryness in the continent. Over Amazonia the aridity increases $23.9 \%$ (for the UNEP index) and 3.1\% (for the Budyko index), suggesting that portions of the Amazonia forest are replaced by dry land area. The semi-arid zone over northeast Brazil expands westward, attaining the interior of north Brazil. In this region the aridity increases $20 \%$ (for the UNEP index) and $0.6 \%$ (for the Budyko index) indicating that areas of humid regime may be occupied by areas with dry land regime. The RCM was also integrated driven by the AOGCM ECHAM5/MPI-OM for the reference climate (CTRL2) and under A1B SRES scenario. The results for the present-day climate are similar in CTRL2 and CTRL, and are in agreement with CRU data. The distribution of the aridity for the present climate seems to be better represented in CTRL using both Budyko and UNEP indices. The changes in aridity (future climate minus control) are higher in the run forced by the A1B SRES scenario. Although the UNEP and Budyko indices show potentialities and limitations to represent the aridity distribution over $S A$, the changes in aridity due to a pseudo-scenario of global warming are higher using the UNEP index. 


\section{Keywords}

\section{Aridity in South America, Surrogate Climate-Change Scenario, Regional Climate Model}

\section{Introduction}

Most of the environmental warming observed in the last decades can be attributed to the increase of anthropogenic greenhouse gases concentration. Projections of future climate change from forcing SRES scenarios using several Atmospheric-Ocean General Circulation Models (AOGCMs) indicate an increase of mean global temperature by about $2^{\circ} \mathrm{C}$ to $5.8^{\circ} \mathrm{C}$ by 2100, as reported by the IPCC Fourth Assessment (AR4). The estimates given by IPCC AR4 suggest that climate change, in particular the increase of temperature, is affecting adversely the ecosystems. Projections of future climate using different AOGCMs indicate that the distribution of the biomes over the entire earth can be modified in future due to global warming leading in general to an increase of the aridity. Expansion of subtropical desert and semi-desert zones in the Northern and Southern Hemispheres and a reduction of the tropical rainforest and boreal forest can occur due to the increase of the greenhouse gases concentration [1]. Recently, [2] using a simple mechanistic model showed that associated to the warmer climate an increase of the drying of land regions may occur over the entire globe in future.

Particularly over Brazil, significant portions of the Amazon forest may be replaced by non-forested areas [3]-[5]. A review of several studies devoted to understanding the risk, process and dynamics of potential Amazon dieback and its implications was given in [6]. In the semi-arid region of Northeast Brazil, the warmer and drier scenarios projected by the IPCC models indicate an increase of the aridity in the region, with negative consequences for the Caatinga biome where large areas have been altered by human activities. Thus, the estimates of future climate suggest a savannization of parts of Amazon and desertification of the semi-arid area of Northeast Brazil, with potential adverse impacts on the rich species diversity in the former region and water resources in the latter.

Most of the studies of the impact of global warming on the biomes over South America are made using AOGCM [3]-[5], Regional Climate Models (RCM) [7] and Potential Vegetation Models (PVM) [8] [9] driving by IPCC scenarios for future climate change. In the present paper, it investigated the feasibility of using a methodology for generating surrogate climate-change scenarios with a RCM [10] to study the impact of global warming on the changes in the aridity in South America, particularly in Brazil. The methodology for generating surrogate climate-change scenarios is dynamically consistent and easy to incorporate in a RCM. It allows us to examine certain processes in isolation [10]-[13]. The model experiment will be designed to explore the response within South America to a pseudo-global warming with an accompanying increase in atmospheric water vapor content. Two aridity indices are used: the Budyko radiative dryness index [14] and the UNEP aridity index [15]. Section 2 gives a short description of the RCM, the methodology employed and the experiment design; the model simulations are presented in Section 3 and Section 4 contains the summary and conclusions.

\section{The Model and Experiment Design}

\section{1) The Regional Climate Model}

The model ICTP RegCM4 [16] is the version 4 of the regional climate model (RegCM) originally developed at the National Center for Atmospheric Research (NCAR) [17]-[19]. The dynamic component of the model is based on the NCAR Pennsylvania State University (MM5) [20]. For application to climate studies, a number of physical parameterizations were incorporated in the model. More details about the model are given in [16]. In the present study modified parameters of BATS land-surface model for vegetation type 6 (tropical rain forest) are used to reduce the rainfall dry bias over tropical South America, as reported in earlier RegCM versions [21].

2) Experiment design

The model domain covers all South America (see Figure 1), following the CORDEX, an international effort to downscale climate projections over the world using RCMs [22]. It is centered at $22^{\circ} \mathrm{S}, 59^{\circ} \mathrm{W}$, and contains $202 \mathrm{EW} \times 192 \mathrm{NS}$ grid points, with a horizontal grid spacing of $50 \mathrm{~km}$ over a rotated Mercator projection. Ten-yr simulations were performed (after discarding a 1 yr spin-up period), extending from 1 January of 1990 to 31 December of 1999. 


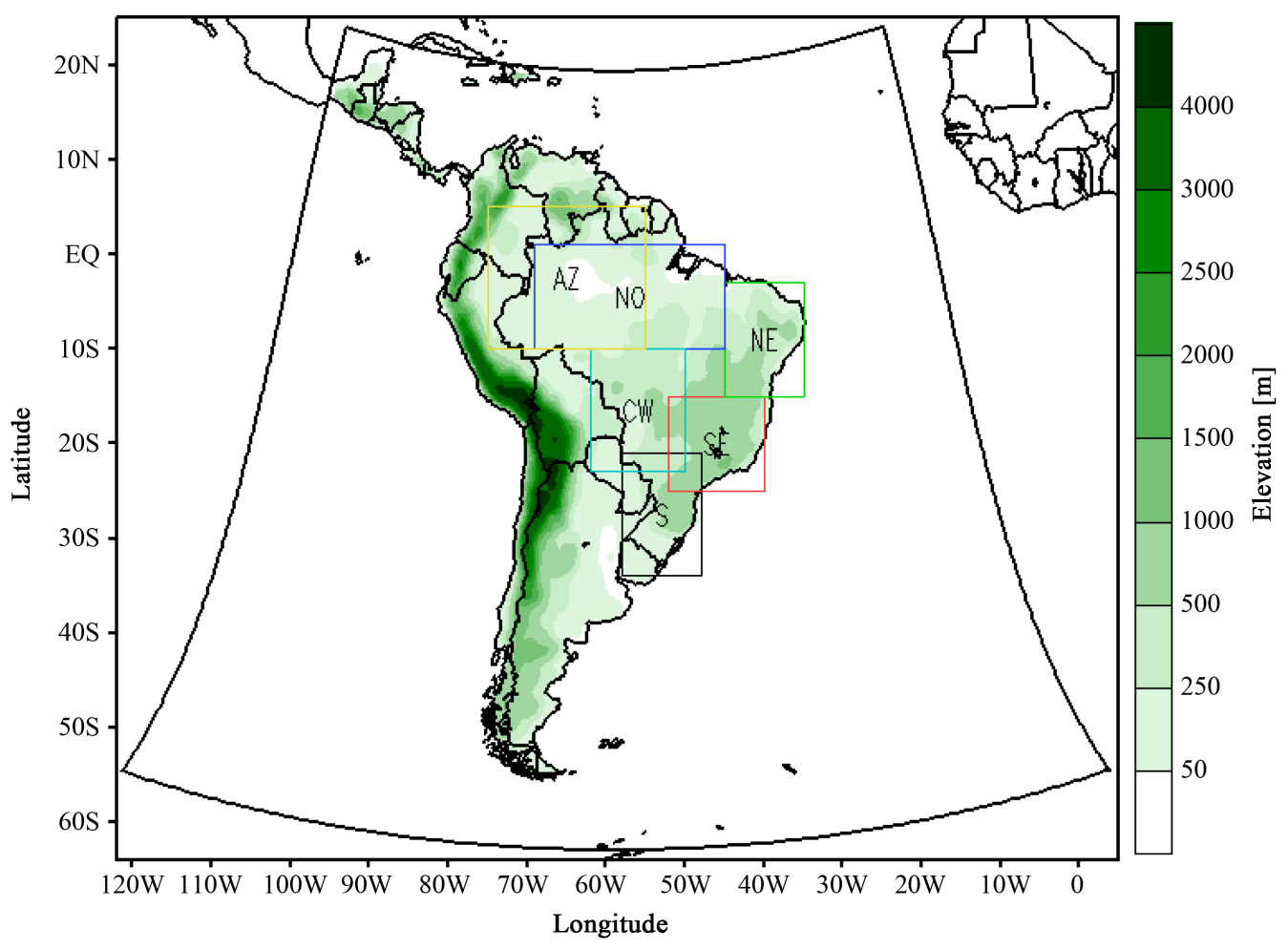

Figure 1. Model domain and topography $(\mathrm{m})$ of South America. Shown are regions of Brazil: $\mathrm{AZ}=$ Amazon $\left(10^{\circ} \mathrm{S}-5^{\circ} \mathrm{N}, 75^{\circ} \mathrm{W}-55^{\circ} \mathrm{W}\right)$, NO $=$ north $\left(10^{\circ} \mathrm{S}-1^{\circ} \mathrm{N}, 69^{\circ} \mathrm{W}-45^{\circ} \mathrm{W}\right)$, $\mathrm{CW}=$ center-west $\left(23^{\circ}-\right.$ $\left.10^{\circ} \mathrm{S}, 62^{\circ} \mathrm{W}-50^{\circ} \mathrm{W}\right), \mathrm{NE}=$ northeast $\left(15^{\circ} \mathrm{S}-3^{\circ} \mathrm{S}, 45^{\circ} \mathrm{W}-35^{\circ} \mathrm{W}\right), \mathrm{SE}=$ southeast $\left(25^{\circ} \mathrm{S}-15^{\circ} \mathrm{S}, 52^{\circ} \mathrm{W}-\right.$ $\left.40^{\circ} \mathrm{W}\right)$ and $\mathrm{S}=$ south $\left(34^{\circ} \mathrm{S}-21^{\circ} \mathrm{S}, 58^{\circ} \mathrm{W}-48^{\circ} \mathrm{W}\right)$.

The control run (CTRL) is initialized with and driven by ECMWF/ERA-Interim reanalysis data [23], while the sensitivity experiment (SURROGATE) is forced by a modified set of initial and boundary conditions. The surrogate climate-change scenario follows the methodology proposed by [10]. It consists of a uniform $3 \mathrm{~K}$ temperature increase with correspondent increase in specific humidity. The relative humidity is left unchanged resulting in an increased flux of water vapor at the boundaries. In this scenario, the ERA-Interim dataset of temperature is increased by $3 \mathrm{~K}$ consistently throughout the atmospheric column, and the sea surface temperature OISST dataset [24] are warmed by $3 \mathrm{~K}$. The atmospheric greenhouse gases concentration of the sensitivity experiment is set to two times its present-day values. A global mean equilibrium surface temperature increase of 3 $\mathrm{K}$ corresponds approximately to a $\mathrm{CO}_{2}$ equivalent concentration of $710 \mathrm{ppm}$ [25].

Although the methodology for generating a surrogate climate change scenario is dynamically consistent and easy to incorporate in a RCM, the surrogate climate change scenario is only an idealized experiment and not a real climate change experiment [13]. In this kind of experiment the response to a combination of a horizontally uniform thermodynamic modification of the initial and external fields plus an unmodified external flow evolution is studied. Otherwise a real climate change would be accompanied by changes in the planetary and synoptic-scale circulation.

The distribution of the aridity over South America is made using the radiative dryness index of Budyko [14] and the UNEP aridity index [15]. The Budyko index has been used in many studies of land-surface effects, climate change and biogeography [26]-[28] and many others. The UNEP index was adopted by UNEP to produce a dryness map (UNEP 1992). The Budyko index, $\mathrm{AI}_{B}$, is defined as $\mathrm{AI}_{B}=\mathrm{R} /(\mathrm{LP})$, where $\mathrm{R}$ is the mean annual net radiation; $\mathrm{P}$, the mean annual precipitation and $\mathrm{L}$ is the latent heat of evaporation. Thresholds for different climate regimes are defined as:

$0<\mathrm{AI}_{\mathrm{B}} \leq 1=$ humid (surplus moisture regime; steppe to forest vegetation)

$1<\mathrm{AI}_{\mathrm{B}} \leq 2=$ semi-humid (moderately insufficient moisture; savanna)

$2<\mathrm{AI}_{\mathrm{B}} \leq 3$ = semi-arid (insufficient moisture; semi-desert)

$\mathrm{AI}_{\mathrm{B}}>3=$ arid (very insufficient moisture; desert) 
The UNEP index, $\mathrm{AI}_{U}$, is defined by $\mathrm{AI}_{U}=\mathrm{P} / \mathrm{PET}$, where $\mathrm{P}$ is the annual precipitation and PET is the annual potential evapotranspiration. $\mathrm{P}$ is provided by the model while PET is calculated using the formula of [29]. Thresholds for different climate regimes are:

$\mathrm{AI}_{\mathrm{U}} \geq 1$ = humid regime

$0.65 \leq \mathrm{AI}_{\mathrm{U}}<1=$ dry land

$0.50 \leq \mathrm{AI}_{\mathrm{U}}<0.65=$ dry sub-humid regime

$0.20 \leq \mathrm{AI}_{\mathrm{U}}<0.50=$ semi-arid regime

$0.05 \leq \mathrm{AI}_{\mathrm{U}}<0.20=$ arid regime

$\mathrm{AI}_{\mathrm{U}}<0.05=$ hyper-arid regime

Net radiation from satellite-based observations calculated in the Global Energy and Water Cycle Experiment (GEWEX) Surface Radiation Budget (SRB) program [30] and precipitation and air temperature from Climate Research Unit (CRU) [31] dataset were used to calculate the observed Budyko and UNEP indices.

\section{Results}

In this section the modeled values of the CTRL are compared with the CRU data and are also compared to SURROGATE experiment.

1) Present-day climate

The model simulates well the general observed pattern of mean annual surface air temperature. The large warm bias occurs in the Amazon region and Argentina (around $+1^{\circ} \mathrm{C}$ ) while a colder bias is simulated over the south and southeast Brazil (around $-1.5^{\circ} \mathrm{C}$ ) and in the south, southwest and west coast of South America (around $-2^{\circ} \mathrm{C}$ ) (Figure 2(f)). The pattern of temperature is somewhat similar for the austral summer. However, the re-

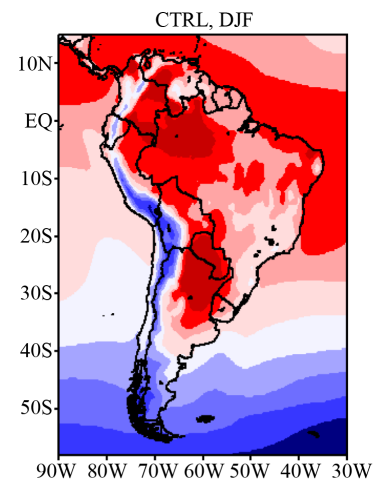

(a)

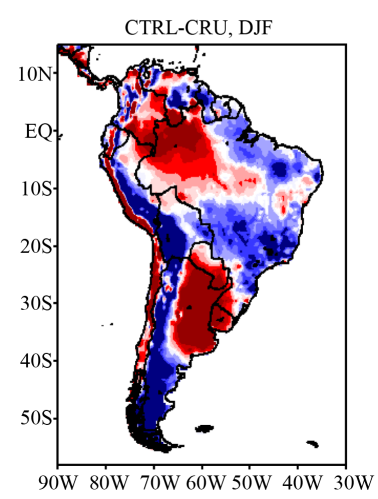

(d)

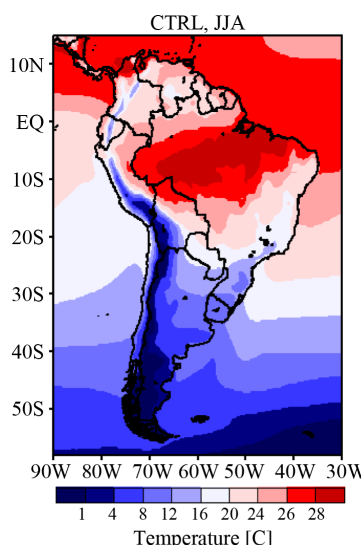

(b)

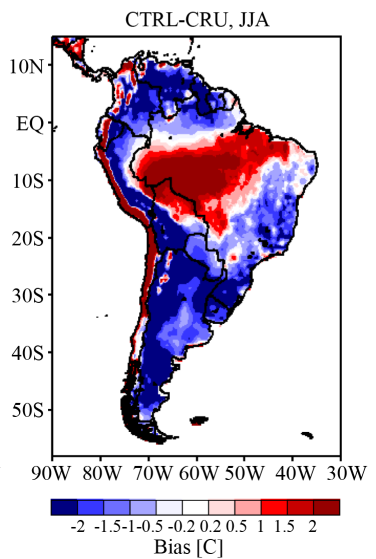

(e)

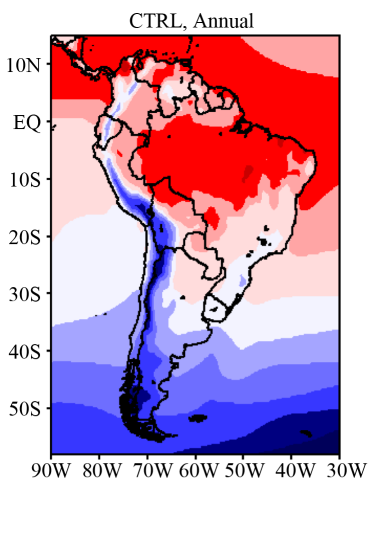

(c)

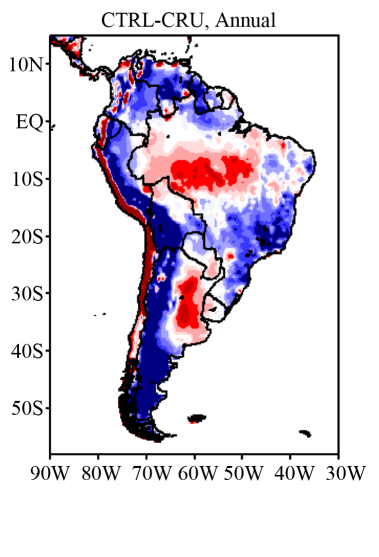

(f)

Figure 2. Mean surface air temperature $\left({ }^{\circ} \mathrm{C}, 1990-1990\right)$ in the control experiment for: (a) DJF; (b) JJA and (c) mean annual, and control experiment minus CRU data for (d) DJF; (e) JJA and mean annual. 
gion of warmer bias over Amazon and Argentina has a wider area and a higher value in summer compared with annual mean (around $2^{\circ} \mathrm{C}$ ) (Figure 2(d)). In the austral winter the modeled temperatures are colder $\left(-1.5^{\circ} \mathrm{C}\right.$ to $-2^{\circ} \mathrm{C}$ ) than CRU data over most of South America except in some parts of the north and center-west regions where they are warmer (around $+2^{\circ} \mathrm{C}$ ) (Figure 2(e)).

The observed precipitation pattern is reproduced by the model over most of the domain (Figures 3(a)-(f)). During austral summer (DJF), the RCM exhibits behavior in the depiction of the South Atlantic Convergence Zone, the relative abundant rainfall in the southern Brazil, western Amazon, and in the west coast of Peru-Ecuador. In austral winter (JJA), the model simulated the northward position of the ITCZ, and rainfall over Colombia and Southern Brazil. In the annual case, the simulated values are also in good agreement with the CRU data, although they are overestimated (around $+1.5 \mathrm{~mm} \cdot \mathrm{day}^{-1}$ ) over the central part of South America and underestimated $\left(-1.5 \mathrm{~mm} \cdot \mathrm{day}^{-1}\right.$ to $\left.-2 \mathrm{~mm} \cdot \mathrm{day}^{-1}\right)$ over the north and south regions of Brazil (Figure 3(f)).

2) Surrogate climate-change scenario

The field of surface air temperature in a surrogate climate change scenario and the difference relative to con-

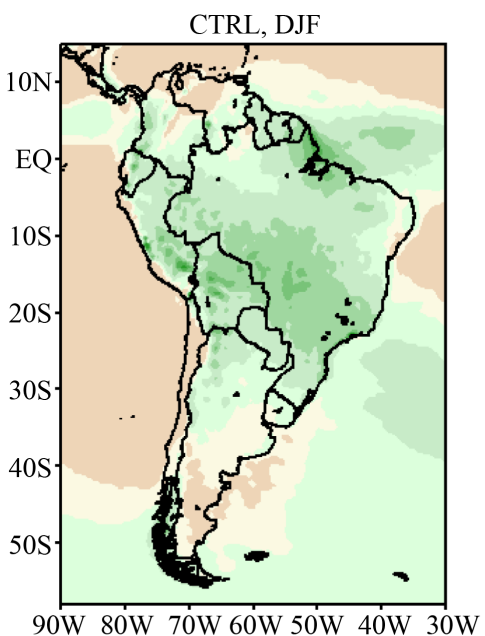

(a)

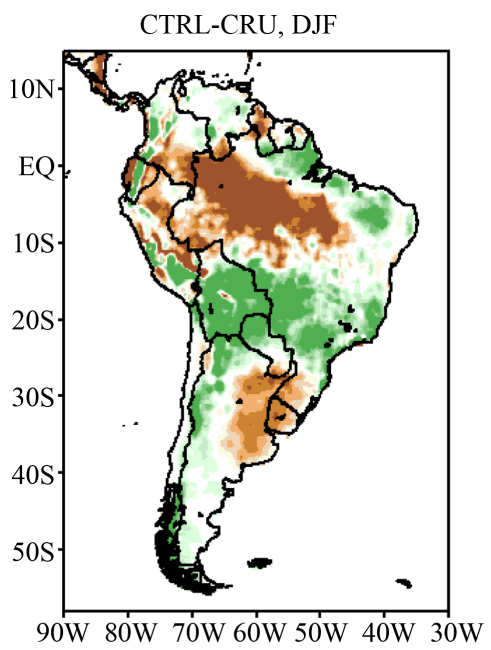

(d)
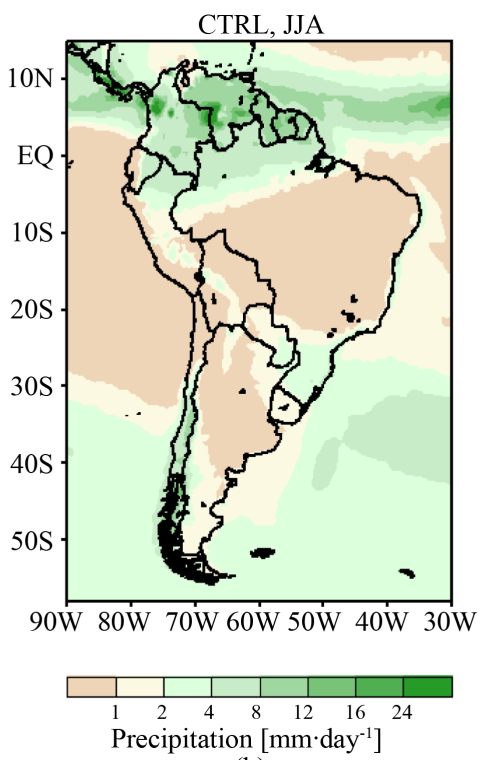

(b)
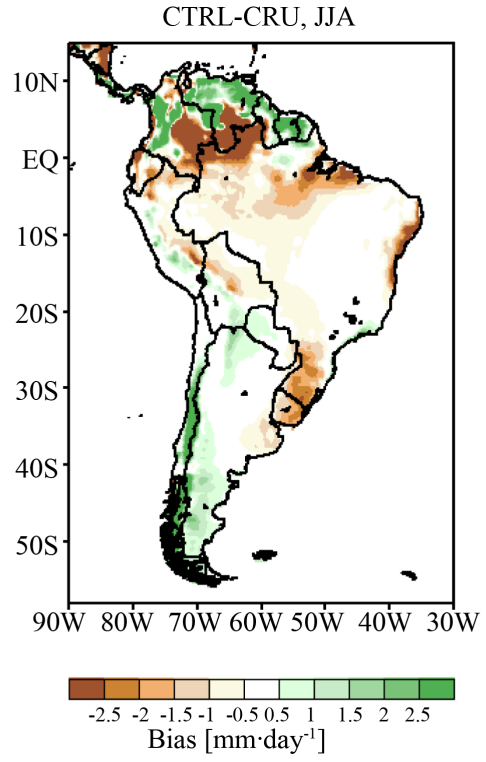

(e)

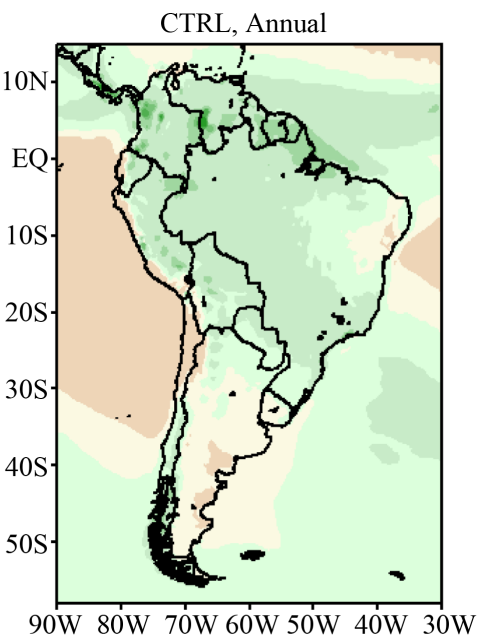

(c)

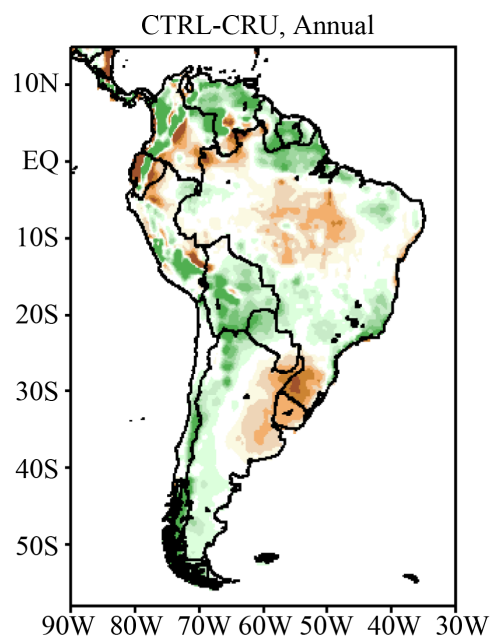

(f)

Figure 3. The same as in Figure 2, but for the precipitation (mm·day ${ }^{-1}$, 1990-1999). 
trol experiment for DJF, JJA and the mean annual are shown in Figures 4(a)-(f). In the austral summer the pseudo-warming scenario shows an increase of temperature $\left(>4^{\circ} \mathrm{C}\right)$ in the northern Brazil, northwestern and southwestern South America. Some areas over the northern Brazil, particularly over Amazon, show an increase of temperature higher than $4.5^{\circ} \mathrm{C}$. The change in temperature for the mean annual presents similar pattern as that in the austral summer. However, the regions with increase of temperature have smaller areas compared with the austral summer, mainly in the northern Brazil and the changes are lower $\left(<4^{\circ} \mathrm{C}\right)$. In the austral winter the region of increase of temperature is shifted from the northern to the central Brazil while the other region in the southwestern South America remains almost the same as in the case of the austral summer and the mean annual. The increase of temperature is in general lower than $4^{\circ} \mathrm{C}$ in these regions.

Figures 5(a)-(f) show the field of precipitation in a surrogate climate change scenario for DJF, JJA and the mean annual and the its difference relative to the control experiment. On the annual basis the pseudo-warming scenario shows an increase of precipitation in the center-west and southeast region of Brazil, north of Bolivia,

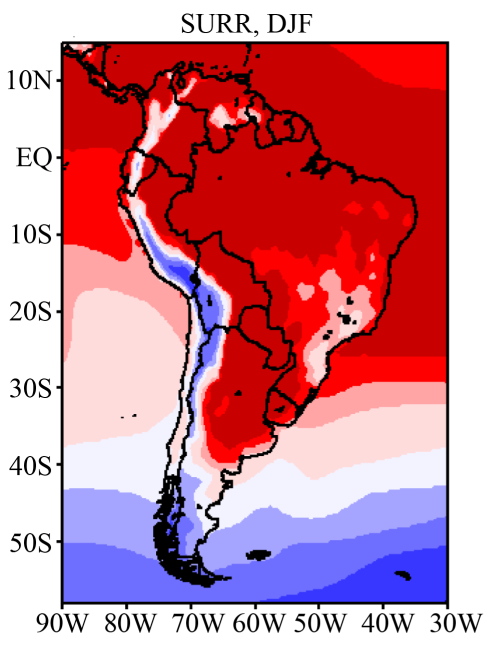

(a)

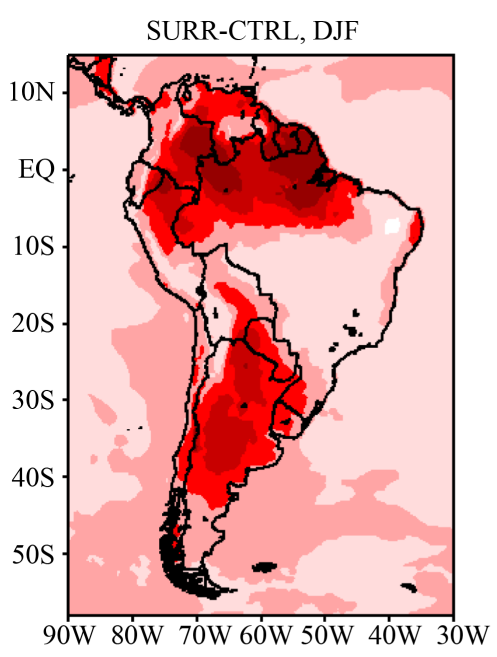

(d)
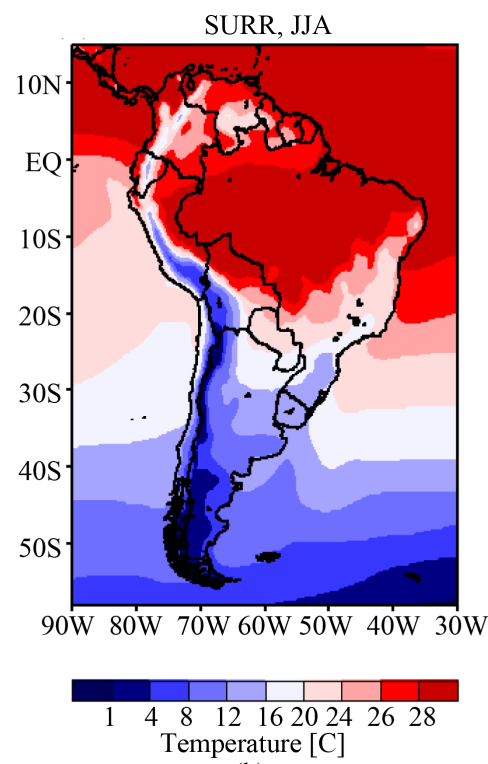

(b)
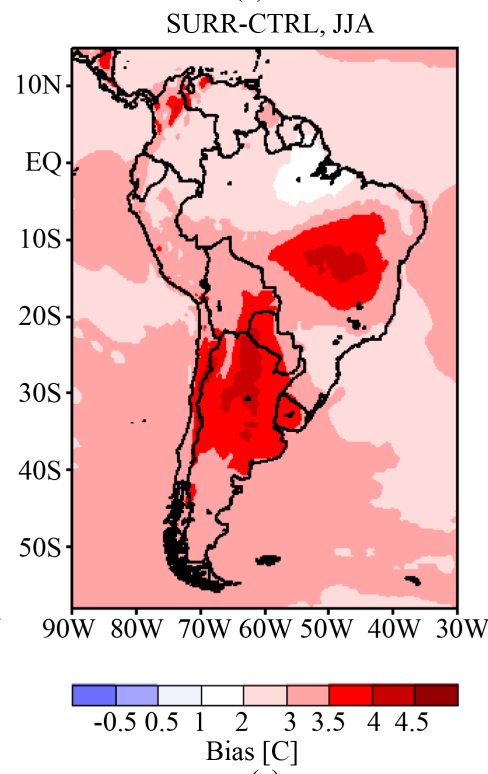

(e)

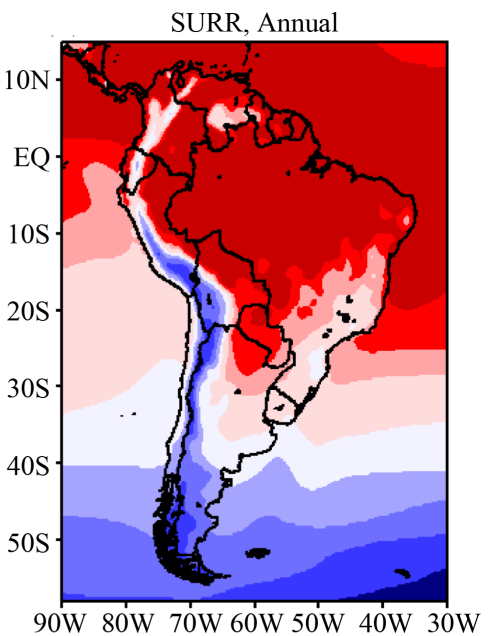

(c)

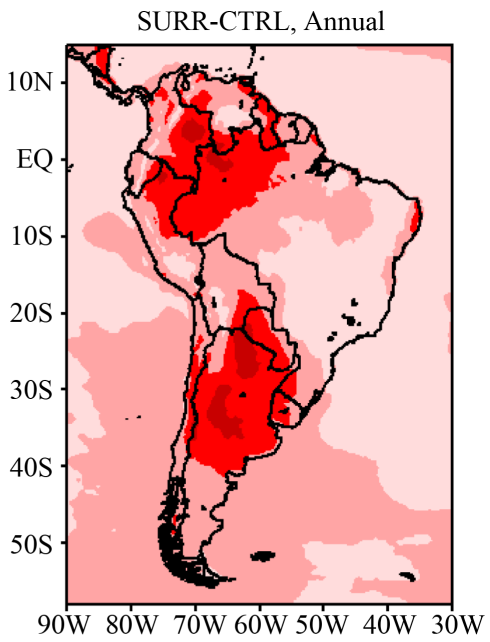

(f)

Figure 4. Mean surface air temperature $\left({ }^{\circ} \mathrm{C}\right)$ in the pseudo-scenario global warming experiment for: (a) DJF; (b) JJA and (c) mean annual and pseudo-scenario experiment minus control for: (d) DJF; (e) JJA and (f) mean annual. 


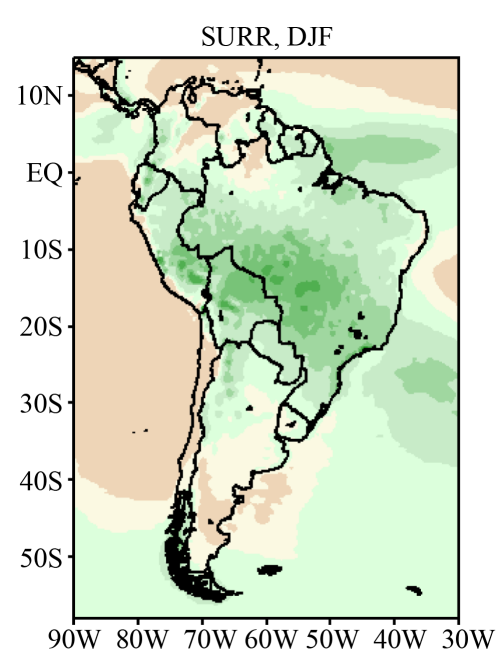

(a)

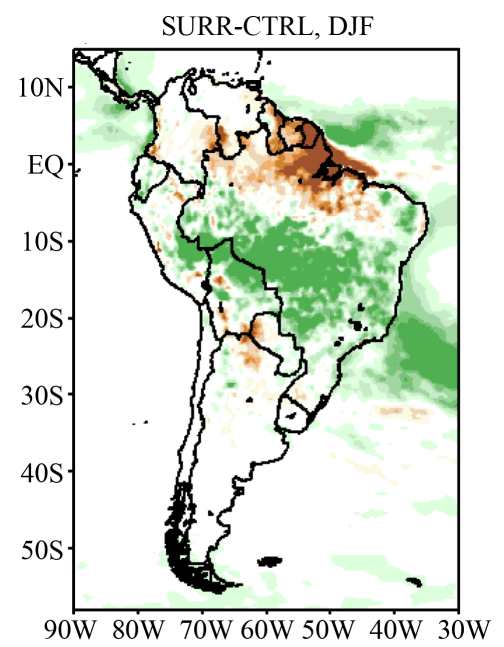

(d)
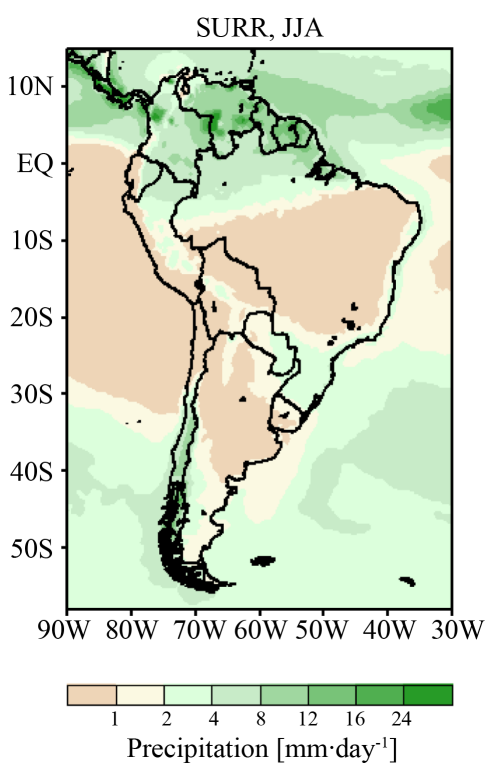

(b)
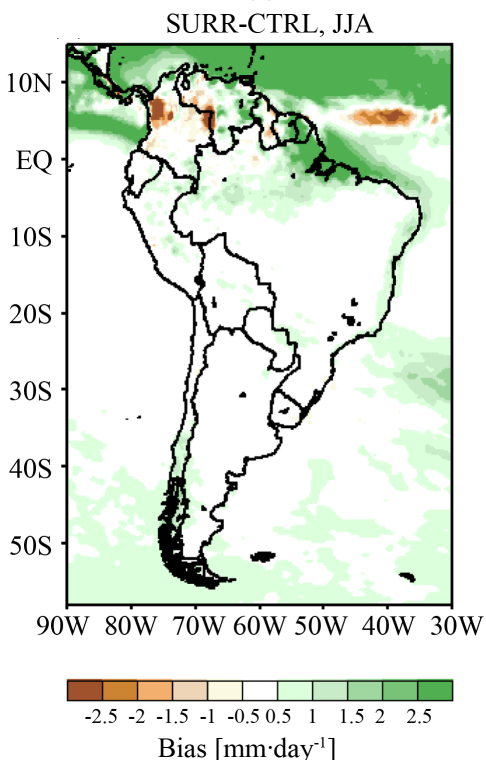

(e)

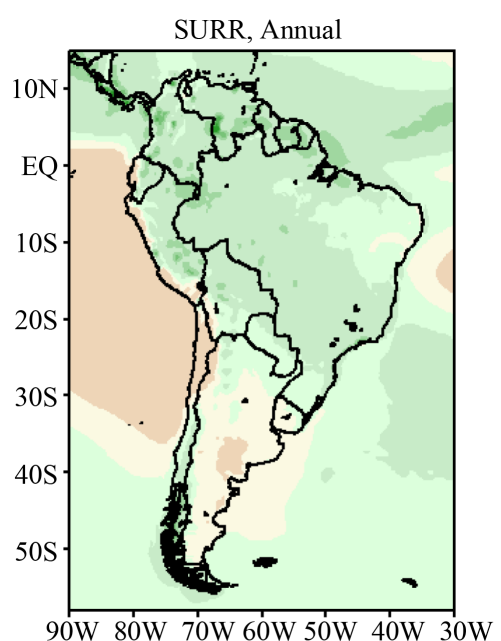

(c)

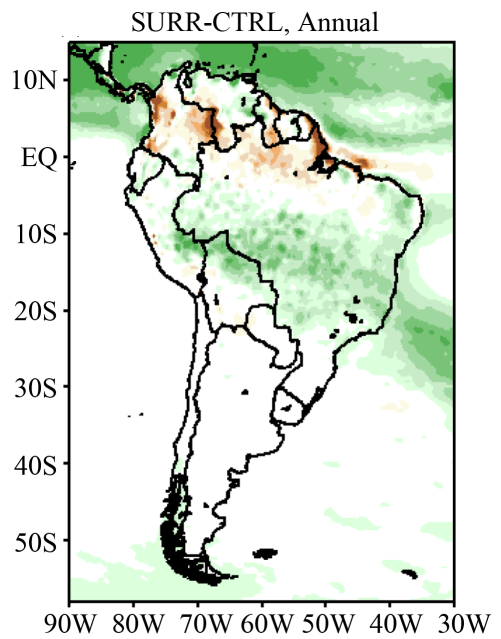

(f)

Figure 5. The same as in Figure 4, but for precipitation $\left(\mathrm{mm} \cdot \mathrm{day}^{-1}\right.$, 1990-1999).

Ecuador and Peru and a decrease of precipitation in the North Brazil and Amazon region. In the northeast Brazil the simulation shows an increase of precipitation in most of the region although a decrease of rainfall in some parts (mainly in the east) is noted. The distribution pattern of precipitation is similar in the austral summer while in the austral winter there is no clear sign of the change in precipitation over almost the entire continent, except over Amazon where the precipitation is increased.

These results are in general agreement with previous experiments on dynamic downscaling of future climate change scenarios performed in various regions of South America, for the Intergovernmental Panel on Climate Change (IPCC) Special Report Emission Scenarios (SRES) A2 and B2 [32]-[34] and are consistent with projections from IPCC AR4 AOGCMs [35], which indicate future warming, rainfall increases in southeastern South America, Ecuador and Peru and decreases in the central and eastern Amazon. However, the present RCM shows an increase of rainfall in most of northeast Brazil although a reduction in some parts (mainly in the east) is noted so that the change in precipitation averaged over the entire area of northeast Brazil is positive (Table 1 ). The increase of rainfall in northeast Brazil in the model simulation is due to the moisture convergence in the Atlantic 
Table 1. Changes in the surface air temperature $\left({ }^{\circ} \mathrm{C}\right)$, precipitation $\left(\mathrm{mm} \cdot \mathrm{day}^{-1}\right)$ and evapotranspiration $\left(\mathrm{mm}^{-1 a y}{ }^{-1}\right)$ in the regions of Brazil indicated in Figure 1.

\begin{tabular}{cccc}
\hline Regions & $\Delta \mathrm{T}\left({ }^{\circ} \mathrm{C}\right)$ & $\Delta \mathrm{P}\left(\mathrm{mm} \cdot \mathrm{day}^{-1}\right)$ & $\Delta \mathrm{E}\left(\mathrm{mm}^{\left.-\mathrm{day}^{-1}\right)}\right.$ \\
\hline $\mathrm{AZ}$ & +3.6 & -0.14 & -0.24 \\
$\mathrm{NO}$ & +3.4 & -0.09 & -0.09 \\
$\mathrm{NE}$ & +3.0 & +1.04 & +0.11 \\
$\mathrm{CW}$ & +2.9 & +0.63 & +0.40 \\
$\mathrm{SE}$ & +2.7 & +1.01 & +0.39 \\
$\mathrm{~S}$ & +3.2 & +0.13 & +0.18 \\
\hline
\end{tabular}

Ocean near the region and the consequent advection of humidity by trade winds towards northeast Brazil (Figure 6). This occurs because the methodology for generating surrogate climate-change scenarios with a regional climate model [10] produces a pseudo-global warming scenario with an accompanying increase in atmospheric water vapor content. In the present simulation this increase of water vapor content also occurs in the adjacent ocean which causes moisture convergence and increase of rainfall over the northeast Brazil, mostly in the interior and coastal regions. Other experiments using this methodology were performed for mid-latitude regions and the model domain also include ocean with similar results [11]-[13]. However, since these experiments were performed for mid-latitudes the heating is not as strong as in tropical regions.

3) Impact on the distribution of the aridity over South America

The distribution of aridity over South America using the radiative dryness index of Budyko for the present climate, SRB/CRU dataset, surrogate climate change scenario and the difference (SURROGATE experiment minus present time) are shown in Figures 7(a)-(d), respectively. Comparing Figures 7(a)-(b) it is noted that the aridity distribution in CTRL experiment using Budyko index is in a general good agreement with that in the SRB/CRU data. The areas with surplus moisture regime in the Amazon region and center of Brazil, the semihumid areas in the interior northeast Brazil and bellow $20^{\circ} \mathrm{S}$, the arid and semi-arid regions in the northeast Brazil and the west coast of South America and the semi-humid areas over Argentina are reproduced by the model. However, some differences are noted. The semiarid and arid zones in the west coast of the continent have a small area compared with the SRB/CRU data. Also, the arid zone in the southern South America is not simulated by the model. The zone of semi-humid and semi-arid region in the east of Brazil is shifted southwards in the SRB/CRU data while in the CTRL it is expanded towards the interior of the continent.

As shown in Figures 7(c)-(d), in the surrogate climate change scenario the aridity increases in the continent except in the east coast, center and southeast Brazil and the south of the continent. The increase of aridity is higher in the north Brazil and Amazon, where areas with humid regime are replaced by semi-humid regime, and in Argentina and the east coast of South America, where areas with moderately insufficient moisture regime are substituted by insufficient moisture and very insufficient moisture regimes. Although in the east coast of Brazil there is a decrease of aridity, in the extreme north-northeast coast and in the northwest of northeast Brazil the aridity increases. Table 2 shows that the change in $\mathrm{AI}_{\mathrm{B}}$ averaged over the entire region is +0.03 and +0.01 in Amazon and north region of Brazil indicating an increase of $3.1 \%$ and $0.6 \%$ in the aridity relative to the control, respectively. This suggests that areas of forest may be replaced by savanna (semi-humid regime). The change in the aridity is also high in the south Brazil $\left(\Delta \mathrm{AI}_{\mathrm{B}}=0.06\right)$ showing an increase of $4.6 \%$. In the center-west and southeast regions of Brazil the change in $\mathrm{AI}_{\mathrm{B}}$ indicates, respectively, a decrease of $12.3 \%$ and $16.9 \%$ in the aridity in these areas. In the northeast Brazil the change in $\mathrm{AI}_{\mathrm{B}}$ is -0.89 suggesting that the aridity is decreased in 28.8\% relative to the CTRL in this area. As commented earlier, the CTRL simulates an incorrect increase of precipitation in this region which leads to lower values of $\mathrm{AI}_{\mathrm{B}}$ and consequently and increase of the humid regime.

The distribution of the aridity over South America using the UNEP aridity index for the present climate, CRU dataset, surrogate climate change scenario and the difference (SURROGATE experiment minus present time) are shown in Figures 8(a)-(d), respectively. The CTRL reproduces the humid regime in the Amazon region, central, southeast and south Brazil and the dry land, dry sub-humid and semi-arid regimes in the northeast Brazil. Also, the region of dry land and dry sub-humid regimes in Argentina is represented by the CTRL. However, the semi-arid zone in northeast Brazil is more prolonged southward in the CRU data than in the CTRL simulation 


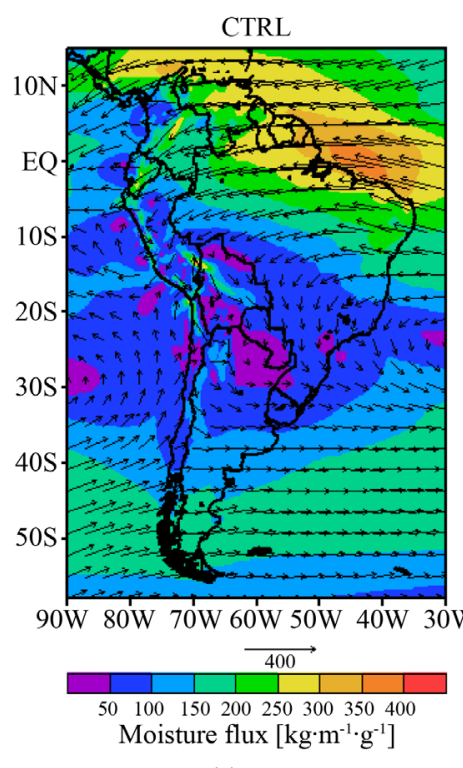

(a)

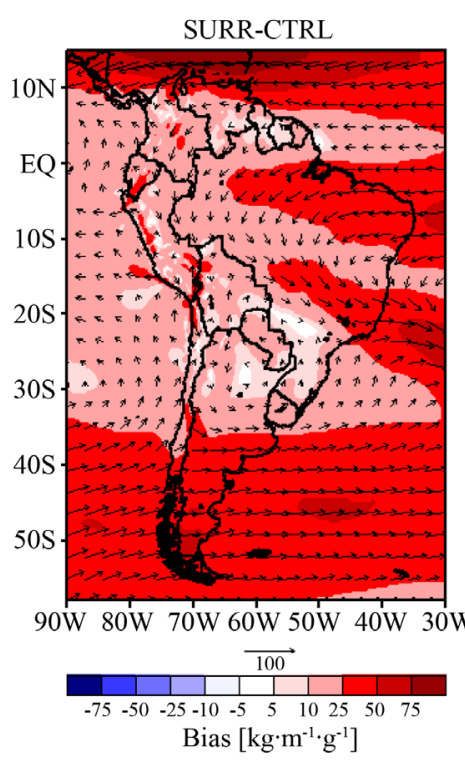

(b)

Figure 6. Mean annual vertically-integrated moisture flux $\left(\mathrm{kg} \cdot \mathrm{m}^{-1} \cdot \mathrm{s}^{-1}\right)$ in the control experiment (a) and in the pseudo-scenario global warming experiment minus control (b).

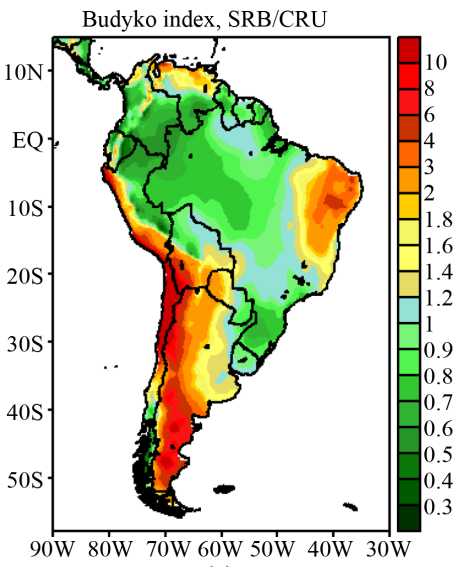

(a)

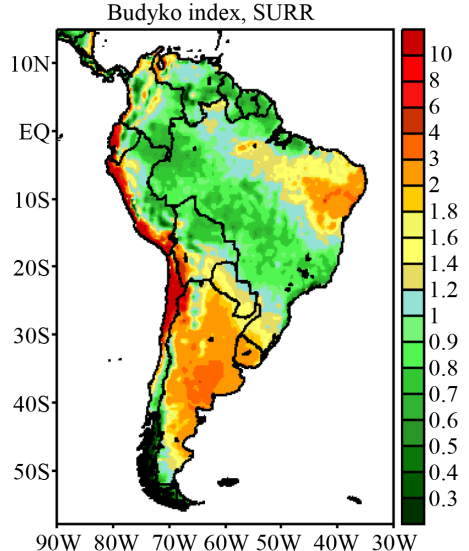

(c)

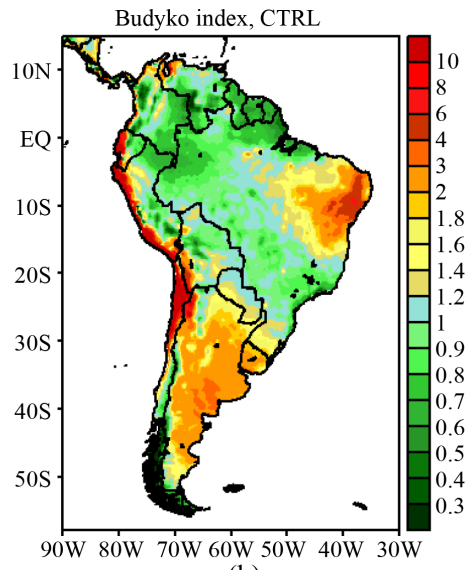

(b)

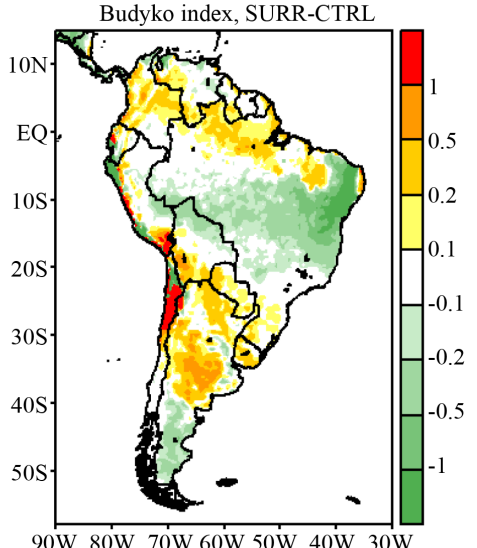

(d)

Figure 7. Distribution of the aridity over South America using the radiative dryness index of Budyko for: (a) SRB/CRU dataset; (b) The present climate; (c) Surrogate climate change scenario; and (d) The difference (surrogate climate change scenario minus present time). 


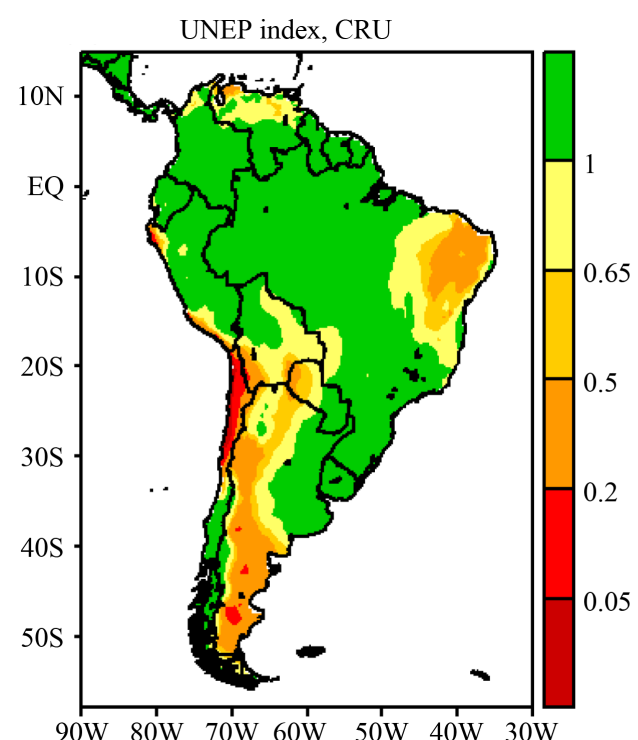

(a)

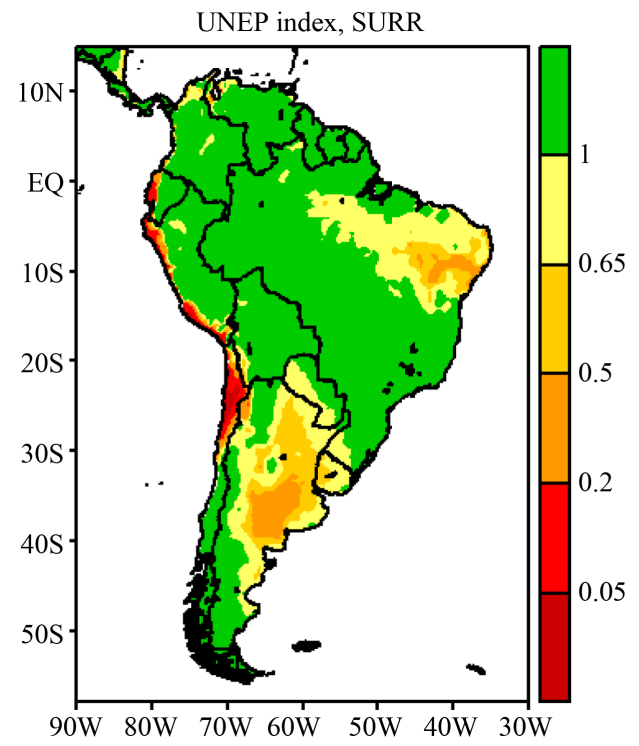

(c)

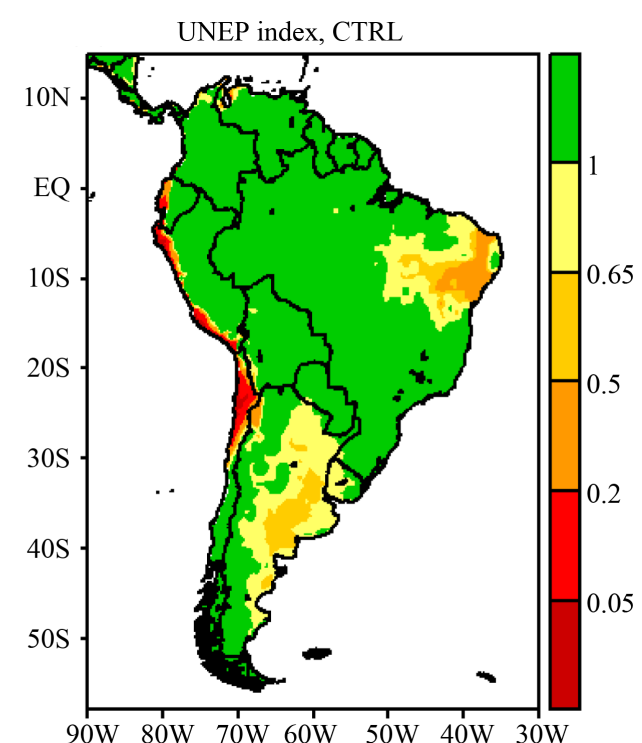

(b)

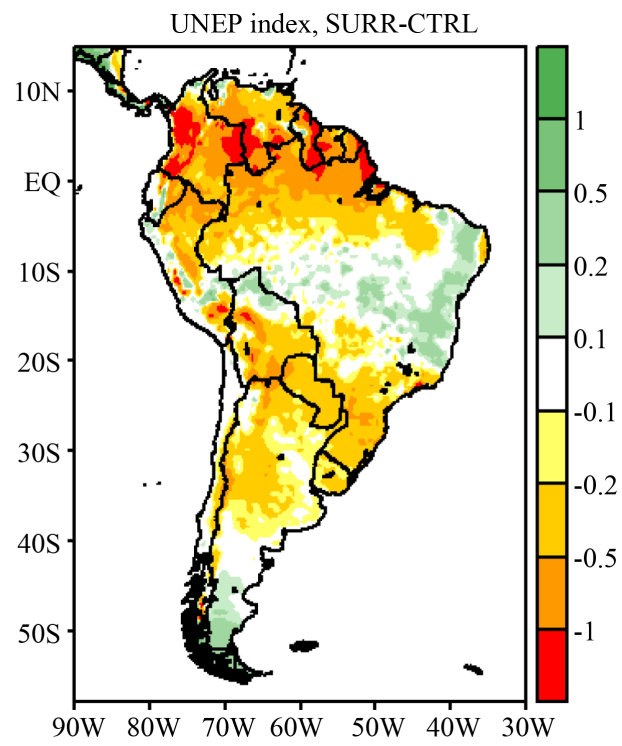

(d)

Figure 8. Distribution of the aridity over South America using the UNEP index for: (a) CRU dataset; (b) The present climate; (c) Surrogate climate change scenario; and (d) The difference (surrogate climate change scenario minus present time).

Table 2. Values of $\mathrm{AI}_{\mathrm{B}}$, the difference, $\Delta \mathrm{AI}_{\mathrm{B}}$, (pseudo-scenario minus control) and the change in $\mathrm{AI}_{\mathrm{B}}$ (pseudo-scenario relative to the control) in the regions of Brazil indicated in Figure 1.

\begin{tabular}{cccc}
\hline Regions & $\mathrm{AI}_{\mathrm{B}}$ (control) & $\Delta \mathrm{AI}_{\mathrm{B}}$ (pseudo-scenario minus control) & $\begin{array}{c}\text { Change in } \mathrm{AI}_{\mathrm{B}} \\
\text { (pseudo-scenario relative to the control) }\end{array}$ \\
\hline $\mathrm{AZ}$ & 0.87 & +0.03 & $+3.1 \%$ \\
$\mathrm{NO}$ & 1.03 & +0.01 & $+0.6 \%$ \\
$\mathrm{CW}$ & 1.00 & -0.12 & $-12.3 \%$ \\
$\mathrm{NE}$ & 3.10 & -0.89 & $-28.8 \%$ \\
$\mathrm{SE}$ & 1.19 & -0.20 & $-16.9 \%$ \\
$\mathrm{~S}$ & 1.38 & +0.06 & $4.6 \%$ \\
\hline
\end{tabular}


and the region of dry land and dry sub-humid regimes in Argentina has a small area compared with the CRU data. The regions of arid regimes in the west coast of South America are well simulated by the CTRL while the semi-arid areas in the south of the continent are replaced by humid regime in the CTRL simulation.

As in the case of Budyko index, the distribution of aridity over South America in the SURROGATE experiment using UNEP index shows an increase of the aridity in the continent (Figures 8(c)-(d)). The dry land zone in the northeast of Brazil is wider and reaches the Amazon and the north region of Brazil. Areas with semi-arid and dry sub-humid regimes substitute areas of dry land regime in Argentina. On the other side, the wetness increases in the south of South America, in some parts of the center of Brazil and along the east coast of the continent.

The changes in the UNEP aridity index averaged over each of the regions of Brazil which are indicated in Figure 1 show an increase of the aridity as response on a pseudo-global warming scenario in all the regions, except in the northeast region (Table 3). The highest decrease in $\mathrm{AI}_{\mathrm{U}}$ (highest increase of the aridity) occurs in the north region, particularly in the Amazon region $\left(\Delta \mathrm{AI}_{\mathrm{U}}=-0.46\right)$. This indicates that the aridity increases 23.9\% relative to the control in the region, suggesting that the Amazon forest may be replaced by non-forested areas. In the north region the mean $\Delta \mathrm{AI}_{\mathrm{U}}=-0.31$ which implies in an increase of $20 \%$ in the aridity, indicating that areas of humid regime may be occupied by areas with dry land regime. In the south and southeast regions the mean $\Delta \mathrm{AI}_{\mathrm{U}}$ are -0.32 and -0.07 , respectively, which signify a reduction of $19.2 \%$ and $3.4 \%$ in the aridity in the areas of humid regime in these regions. Although in some parts of the center of Brazil the wetness increases (Figure 8(c)) the change in the averaged $\mathrm{AI}_{U}$ over the entire center-west region is -0.1 , showing an increase of the aridity of $6.5 \%$. The aridity decreases in the northeast Brazil $\left(\Delta \mathrm{AI}_{\mathrm{U}}=0.02\right)$. This is due to the false increase in the precipitation in this region, as occurred in the case of the Budyko index. However, in some parts of northeast Brazil, such as the northwest and the extreme northeast coast the aridity increases, as shown in Figure 7(d) and Figure 8(d).

4) Comparison with the RegCM4 integrated using the AOGCM ECHAM5/MPI-OM for the reference climate (1989-1999) and under A1B SRES scenario (2089-2099).

Since the pseudo-global warming scenario doesn't consider the dynamic effects associated with the climate changes, it is important to compare the SURROGATE experiment with a run with a more complete scenario. This allows us to verify the differences of a more local/direct climate change impact (with the surrogate climate scenario) and the impacts considering the global circulation and large-scale forcing from GCMs. For this purpose the RegCM4 was integrated driven by the AOGCM ECHAM5/MPI-OM for the reference climate (19891999) (named CTRL2) and under A1B SRES scenario (2089-2099). The ECHAM5/MPI-OM [36] is one of the most successful models to simulate the tropical climate in an intercomparison of AOGCMs participating in the IPCC AR4 [25] [37]. The IPCC A1B SRES represents an intermediate emission (stabilization) scenario for future climate projections [38].

The results for the present-day climate are similar in CTRL2 and CTRL, and are in agreement with CRU data (figure not shown). Comparing Figure 7(b) and Figure 9(a) it can be seen that the distribution of the aridity in CTRL and CTRL2 using Budyko index shows some differences in most of South America. For example, in northeast Brazil there is a zone of humid regime in CTRL2 while semi-arid and arid zones appear in CTRL. Also, in CTRL the region of humid regime is located towards the northwestern South America while it is in the center-west of the continent in CTRL2. In the case of UNEP index, again areas of humid regime are present in northeast Brazil in CTRL2 (Figure 9(d)) while in CTRL there are areas of dry land, dry sub-humid and semi-

\begin{tabular}{cccc} 
Table 3. The same as in Table 2 but for $\mathrm{AI}_{\mathrm{U}}$ & \\
\hline Regions & $\mathrm{AI}_{\mathrm{U}}$ (control) & $\begin{array}{c}\Delta \mathrm{AI}_{\mathrm{U}} \\
\text { (pseudo-scenario minus control) }\end{array}$ & $\begin{array}{c}\text { Change in } \mathrm{AI}_{\mathrm{U}} \\
\text { (pseudo-scenario relative to the control) }\end{array}$ \\
\hline $\mathrm{AZ}$ & 1.92 & -0.46 & $-23.9 \%$ \\
$\mathrm{NO}$ & 1.53 & -0.31 & $-20.0 \%$ \\
$\mathrm{CW}$ & 1.56 & -0.10 & $-6.5 \%$ \\
$\mathrm{NE}$ & 0.65 & +0.02 & $+3.5 \%$ \\
$\mathrm{SE}$ & 1.99 & -0.07 & $-3.4 \%$ \\
$\mathrm{~S}$ & 1.66 & -0.32 & $-19.2 \%$ \\
\hline
\end{tabular}




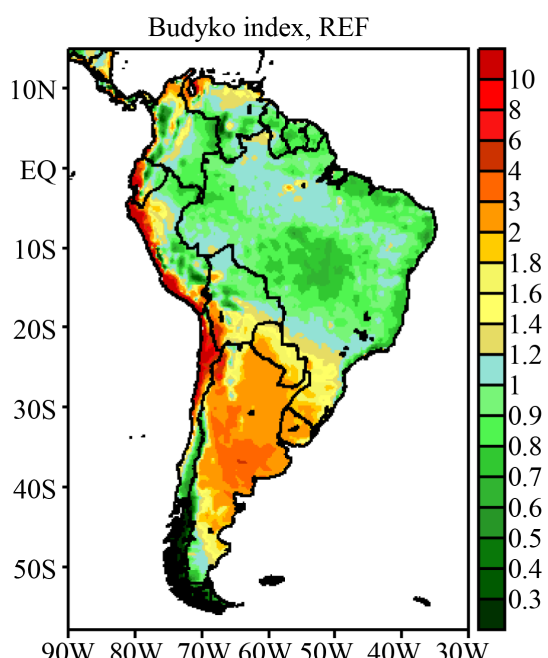

(a)

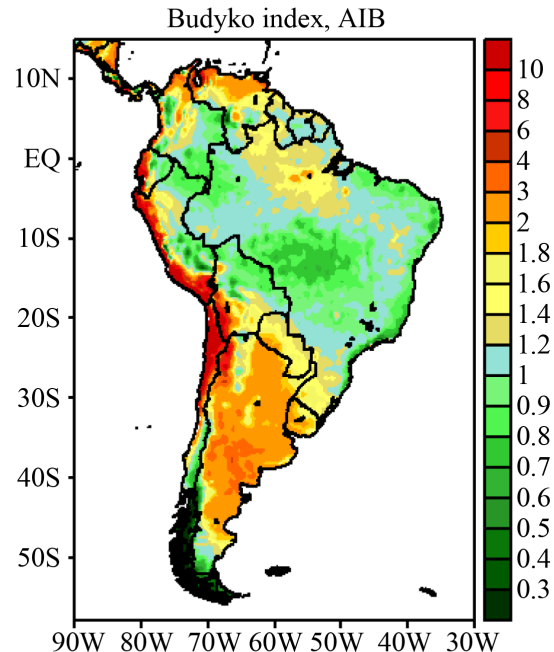

(b)

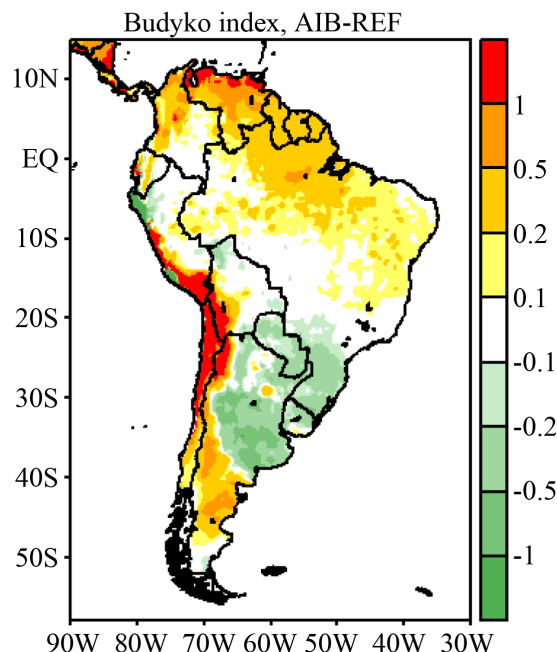

(c)

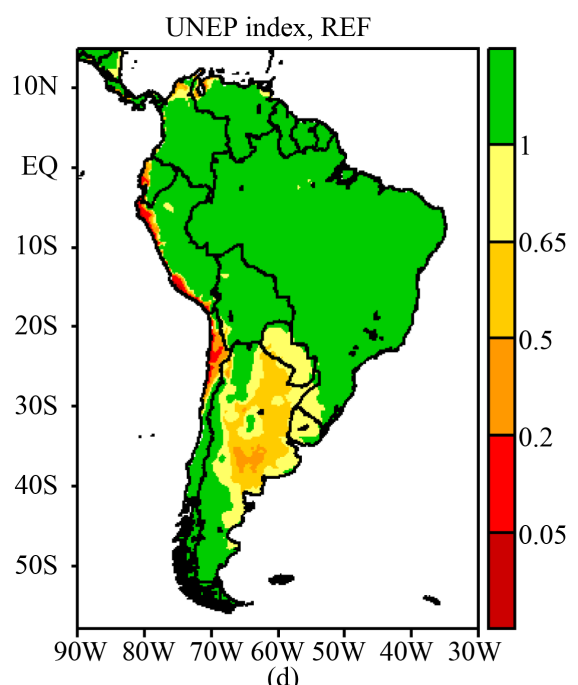

(d)

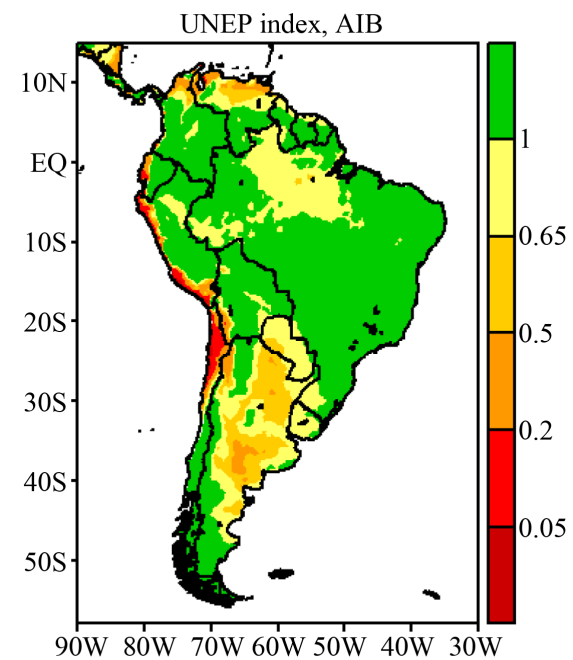

(e)

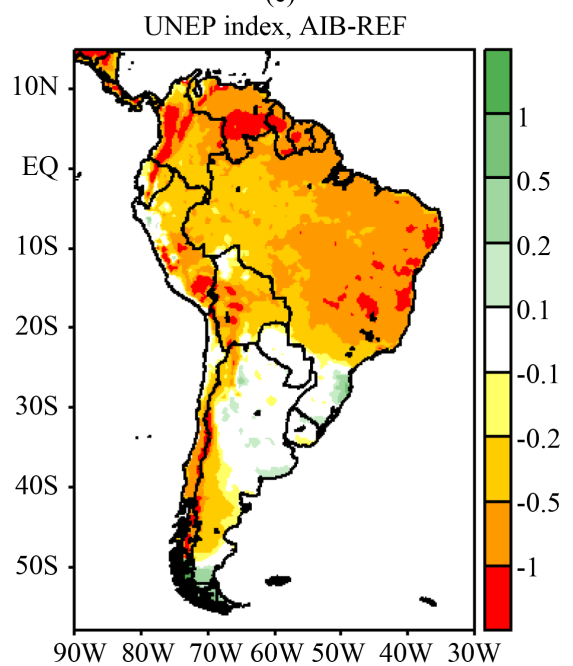

(f)

Figure 9. Distribution of the aridity over South America in the run integrated using the AOGCM ECHAM5/MPI-OM for the Budyko index: (a) For reference climate (1990-1999) (CTRL2); (b) In the run forced by A1B SRES scenario (2090-2100); and (c) The difference in relation to CTRL2; (d), (e) and (f): the same as in (a), (b) and (c), but for the UNEP index. 
arid regimes (Figure $\mathbf{8}(\mathbf{b})$ ). Thus, the distribution of the aridity for then present climate seems to be better represented in CTRL using both Budyko and UNEP indices. The main difference between the results of the run with surrogate climate (Figure 7(c) and Figure 8(c)) and those of the run forced by A1B SRES scenario occurs in the northeast Brazil and Amazon. Although the dry land zone in the northeast of Brazil is wider and reaches the Amazon in the surrogate experiment, in the run forced by A1B SRES it is located in Amazon and not in northeast Brazil (Figures 9(b)-(e)). However, the run forced by A1B SRES scenario shows a decrease of precipitation over northeast of Brazil, which is opposite to what is found in the SURROGATE experiment. This can be due to the fact that the methodology for generating surrogate climate-change scenario produces a pseudoglobal warming scenario with an accompanying increase in atmospheric water vapor content which favors a wetter regime in the region, as commented earlier. The results of the run forced by A1B SRES scenario show that there is a general increase of the aridity in the continent (Figures 9(c)-(f)), as in the case of the SURROGATE experiment (Figure 7(d) and Figure 8(d)). Also, like in the surrogate climate-change experiment the changes in $\mathrm{AI}_{\mathrm{U}}$ are higher than in $\mathrm{AI}_{\mathrm{B}}$ (Table 4). However, a higher increase of aridity is noted in A1B SRES experiment, mainly in the case of the UNEP index (Figure 9(f)). The values of $\mathrm{AI}_{\mathrm{B}}$ and $\mathrm{AI}_{\mathrm{U}}$ in the run forced by A1B SRES (Table 4) are higher compared with those in the surrogate scenario experiment (Table 2 and Table 3) showing that the changes in aridity (future climate minus control) are higher in the run forced by the A1B SRES scenario. The reason for the higher changes in $\mathrm{AI}_{U}$ compared to $\mathrm{AI}_{\mathrm{B}}$ may be due to fact that $\mathrm{AI}_{U}$ depends on potential evapotranspiration which is derived from the air surface temperature. An increment of the air surface temperature caused by the surrogate climate change scenario may provoke a large change compared to the control. Also, monthly mean temperatures are considered so that situations such as warmer summer and winter may increase the potential evapotranspiration. In other hand, $\mathrm{AI}_{\mathrm{B}}$ depends on the annual net surface radiation so that the changes are lower. In spite of the differences, the methodology for generating surrogate climate scenario seems to be useful to study the distribution of the aridity in South America since it is capable for reproducing the overall behaviour of the changes in the aridity in the continent associated with global warming in future climate.

\section{Summary and Conclusions}

The impact of pseudo-global warming on the distribution of the aridity over South America is investigated. For this purpose the methodology for generating surrogate climate-change scenarios with a regional climate model is employed. Two aridity indices are used: the dryness index of Budyko and the UNEP aridity index. The results are in agreement and consistent with other RCM and AOGCM studies for future climate in South America which indicate future warming; rainfall increases in southeastern South America, Ecuador and Peru and decreases in the central and eastern Amazon.

In general the distribution of aridity for the present climate simulated by the model is in agreement with observations. For both the Budyko and UNEP indices, the model reproduces the humid and semi-arid zones in the Amazon region and northeast Brazil, respectively, and arid zones of the west coast and southern South America. However, the semi-arid region in the northeast Brazil is shifted southwards in the observed data while in the model it is expanded towards the interior of the continent.

The distribution of the aridity over South America in surrogate climate change scenario shows a general increase of the aridity in the continent using both Budyko and UNEP indices, except in the center and the east coast Brazil and in the south of the continent. Particularly, over Amazon there is an increase of the aridity of

Table 4. Values of $\mathrm{AI}_{\mathrm{B}}$ and $\mathrm{AI}_{\mathrm{U}}$ and the relative changes in the $\mathrm{A} 1 \mathrm{~B}$ SRES experiment in the regions of Brazil indicated in Figure 1.

\begin{tabular}{ccccccc}
\hline Regions & $\mathrm{AI}_{\mathrm{B}}$ & $\Delta \mathrm{AI}_{\mathrm{B}}$ & $\mathrm{AI}_{\mathrm{B}}(\%)$ & $\mathrm{AI}_{\mathrm{U}}$ & $\Delta \mathrm{AI}_{\mathrm{U}}$ & $\mathrm{AI}_{\mathrm{U}}(\%)$ \\
$\mathrm{AZ}$ & 0.95 & +0.16 & +16.5 & 1.62 & -0.52 & -31.9 \\
$\mathrm{NO}$ & 0.98 & +0.19 & +19.5 & 1.55 & -0.51 & -33.0 \\
$\mathrm{CW}$ & 0.99 & -0.04 & -3.8 & 1.78 & -0.48 & -26.7 \\
$\mathrm{NE}$ & 1.02 & +0.15 & +14.7 & 1.99 & -0.67 & -33.7 \\
$\mathrm{SE}$ & 1.06 & +0.04 & +4.0 & 2.32 & -0.68 & -29.2 \\
$\mathrm{~S}$ & 1.65 & -0.21 & -12.5 & 1.26 & -0.07 & -5.9 \\
\hline
\end{tabular}


23.9\% (UNEP index) and 3.1\% (Budyko index) relative to the control, suggesting that portions of the Amazon forest may be substituted by non-forest areas. In northeast Brazil, the semi-arid zone is wide and reaches the interior of the north Brazil. In this region, the UNEP index indicates an increase of $20 \%$ in the aridity while the Budyko index shows an increase of $0.6 \%$ relative to the control, suggesting that areas of humid regime may be occupied by areas with dry land regime.

In summary, the methodology for generating surrogate climate-change scenarios with a regional climate model seems to be a useful tool for studying the future changes in the aridity over South America. The use of the UNEP aridity index and the Budyko radiative dryness index shows potentialities and limitations to represent the aridity distribution for the present climate and surrogate climate scenario. Although the impact on the aridity distribution due to a pseudo-global warming scenario are almost similar using Budyko and UNEP indices, the changes are higher in the case of the UNEP index.

\section{Acknowledgements}

Thanks are due to Dr. Erika Coppola and the ICTP group for providing the RegCM4 code. Thanks are also due to Dr. Vadlamudi B. Rao for going through the manuscript.

\section{References}

[1] Meehl, G.A., Stocker, T.F., Collins, W.D., Friedlingstein, A.T., Gaye, A.T., Gregory, J.M., Kitoh, A., Knutti, R., Murphy, J.M., Noda, A., Raper, S.C.B., Watterson, I.G., Weaver, A.J. and Zhao, Z. (2007) Global Climate Projections. In: Climate Change 2007: The Physical Science Basis, Contribution of Working Group I to the Fourth Assessment Report of the Intergovernmental Panel on Climate Change, Cambridge University Press, Cambridge, 747-845.

[2] Franchito, S.H., Rao, V.B. and Moraes, E.C. (2011) Impact of Global Warming on the Geobotanic Zones: An Experiment with a Statistical-Dynamical Climate Model. Climate Dynamics, 37, 2011-2034. http://dx.doi.org/10.1007/s00382-010-0952-6

[3] Cox, P.M., Betts, R.A., Collins, M., Harris, P.P., Huntingford, C. and Jones, C.D. (2004) Amazonian Forest Dieback under Climate-Carbon Cycle Projections for the $21^{\text {st }}$ Century. Theoretical and Applied Climatology, 78, 137-156. http://dx.doi.org/10.1007/s00704-004-0049-4

[4] Betts, R.A., Cox, P.M., Collins, M., Harris, P.P., Huntingford, C. and Jones, C.D. (2004) The Role of Ecosystem-Atmosphere Interactions in Simulated Amazonian Precipitation Decrease and Forest Dieback under Global Climate Warming. Theoretical and Applied Climatology, 78, 157-175. http://dx.doi.org/10.1007/s00704-004-0050-y

[5] Cook, K.H. and Vizy, K.H. (2008) Effects of Twenty-First-Century Climate Change on the Amazon Rain Forest. Journal of Climate, 21, 542-560. http://dx.doi.org/10.1175/2007JCLI1838.1

[6] Vergara, W. and Scholz, S.M. (2010) Assessment of the Risk of Amazon Dieback. The World Bank, Washington, D.C., 96.

[7] da Silva, R.R., Werth, D. and Avissar, R. (2008) Regional Impacts of Future Land-Cover on the Amazon Basin WetSeason Climate. Journal of Climate, 21, 1153-1170. http://dx.doi.org/10.1175/2007JCLI1304.1

[8] Oyama, M.D. and Nobre, C.A. (2003) A New Climate-Vegetation Equilibrium State for the Tropical South America. Geophysical Research Letters, 30, 2199. http://dx.doi.org/10.1029/2003GL018600

[9] Salazar, L.F., Nobre, C.A. and Oyama, M.D. (2007) Climate Change Consequences on the Biome Distribution in Tropical South America. Geophysical Research Letters, 34, L09708. http://dx.doi.org/10.1029/2007GL029695

[10] Schar, C., Christoph, F., Lutthi, D. and Davies, H.C. (1996) Surrogate Climate-Change Scenarios for Regional Climate Models. Geophysical Research Letters, 23, 669-672. http://dx.doi.org/10.1029/96GL00265

[11] Seneviratne, S., Pal, J., Eltahir, E. and Schar, C. (2002) Summer Dryness in a Warmer Climate: A Process Study with a Regional Climate Model. Climate Dynamics, 20, 69-85. http://dx.doi.org/10.1007/s00382-002-0258-4

[12] Im, E., Coppola, E., Giorgi, F. and Bi, X. (2010) Local Effects of Climate Change over the Alpine Region: A Study with a High Resolution Regional Climate Model with a Surrogate Climate Change Scenario. Geophysical Research Letters, 37, Article ID: L05704. http://dx.doi.org/10.1029/2009GL041801

[13] Winter, J.M. and Eltahir, E.A.B. (2012) Modeling the Hydroclimatology of the Midwestern United States. Part 2: Future Climate. Climate Dynamics, 38, 595-611. http://dx.doi.org/10.1007/s00382-011-1183-1

[14] Budyko, M.I. (1958) The Heat Balance of the Earth’s Surface. Translated by N. A. Stepanova, U.S. Department of Commerce, Washington DC, 259 p.

[15] UNEP (1992) World Atlas of Desertification. Edward Arnold, London. 
[16] Giorgi, F., Coppola, E., Solmon, F., Mariotti, L., Sylla, M.B., Bi, X., et al. (2012) RegCM4: Model Description and Preliminary Tests over Multiple CORDEX Domains. Climate Research, 52, 7-29. http://dx.doi.org/10.3354/cr01018

[17] Giorgi, F., Marinucci, M.R. and Bates, G.T. (1993) Development of a Second-Generation Regional Climate Model (RegCM2). Part I: Boundary-Layer and Radiative Transfer Processes. Monthly Weather Review, 121, 2794-2813. http://dx.doi.org/10.1175/1520-0493(1993)121<2794:DOASGR>2.0.CO;2

[18] Giorgi, F., Marinucci, M.R., Bates, G.T. and De Canio, G. (1993) Development of a Second-Generation Regional Climate Model (RegCM2). Part II: Convective Processes and Assimilation of Lateral Boundary Conditions. Monthly Weather Review, 121, 2814-2832. http://dx.doi.org/10.1175/1520-0493(1993)121<2814:DOASGR>2.0.CO;2

[19] Pal, J.S., Giorgi, F., Bi, X.Q., Elguindi, N., Solmon, F., Rauscher, S.A., et al. (2007) Regional Climate Modeling for the Developing World: The ITCP RegCM3 and RegNET. Bulletin of the American Meteorological Society, 88, 13951409. http://dx.doi.org/10.1175/BAMS-88-9-1395

[20] Grell, G.A., Dudhia, J. and Stauffer, D.R. (1994) A Description of the Fifth Generation Penn State/NCAR Mesoscale Model (MM5). National Center for Atmospheric Research Tech Note NCAR/TN-398 +STR, NCAR, Boulder.

[21] daRocha, R.P., Cuadra, S.V., Reboita, M.S., Kruger, L.F., Ambrizzi, T. and Krusche, N. (2012) Effects of RegCM3 Parameterizations on Simulated Rainy Season over South America. Climate Research, 52, 253-265. http://dx.doi.org/10.3354/cr01065

[22] Giorgi, F., Jones, C. and Asrar, G. (2009) Addressing Climate Information Needs at the Regional Level: The CORDEX Framework. WMO Bulletin, 58, 175-183.

[23] Dee, D.P., Uppala, S.M., Simmons, A.J., Berrisford, P., Poli, P., Kobayashi, S., et al. (2011) The ERA-Interim Reanalysis: Configuration and Performance of the Data Assimilation System. Quarterly Journal of the Royal Meteorological Society, 137, 553-597. http://dx.doi.org/10.1002/qj.828

[24] Reynolds, R.W., Rayner, N.A., Smith, T.M., Stokes, D.C., Diane, C. and Wang, W. (2002) An Improved in Situ and Satellite SST Analysis for Climate. Journal of Climate, 15, 1609-1625. http://dx.doi.org/10.1175/1520-0442(2002)015<1609:AIISAS >2.0.CO;2

[25] Randall, D.A., Wood, R.A., Bony, S., Colman, R., Fichefet, T., Fyfe, J., et al. (2007) Climate Models and Their Evaluation. In: Climate Change 2007: The Physical Sciences Basis, Contribution of Working Group I to the Fourth Assessment Report of the Intergovernmental Panel on Climate Change, Cambridge University Press, Cambridge.

[26] Arora, V.K. (2002) The Use of the Aridity Index to Assess Climate Change Effect on Annual Runoff. Journal of Hydrology, 265, 164-177. http://dx.doi.org/10.1016/S0022-1694(02)00101-4

[27] Sun, Y.I., Yan, X.D. and Xie, D.T. (2006) Analyzing Vegetation-Climate Interactions in China Based on Budyko’s Indices. Resources Science, 28, 23-29. (In Chinese with English Abstract)

[28] Gao, X.J. and Giorgi, F. (2008) Increased Aridity in the Mediterranean Region under Greenhouse Gas Forcing Estimated from High Resolution Simulations with a Regional Climate Model. Global and Planetary Change, 62, 195-209. http://dx.doi.org/10.1016/j.gloplacha.2008.02.002

[29] Thornthwaite, C.W. (1948) An Approach toward a Rational Classification of Climate. Geographical Review, 38, 55-94. http://dx.doi.org/10.2307/210739

[30] Gupta, S.K., Stackhouse, P.W., Cox, S.J., Mikovitz, J.C. and Zhang, T. (2006) 22-Year Surface Radiation Budget Data Set. GEWEX News, 16, 12-13.

[31] New, M., Hulme, M. and Jones, P. (1999) Representing Twentieth Century Space-Time Climate Variability. Part 1: Development of a 1961-90 Mean Monthly Terrestrial Climatology. Journal of Climate, 12, 829-856. http://dx.doi.org/10.1175/1520-0442(1999)012<0829:RTCSTC >2.0.CO;2

[32] Soares, W. and Marengo, J.A. (2009) Assessments of Moisture Fluxes East of the Andes in South America in a Global Warming Scenario. International Journal of Climatology, 29, 1395-1414. http://dx.doi.org/10.1002/joc.1800

[33] Urrutia, R. and Vuille, M. (2009) Climate Change Projections for the Tropical Andes Using a Regional Climate Model: Temperature and Precipitation Simulations for the End of the 21st Century. Journal of Geophysical Research, 114, Article ID: D02108. http://dx.doi.org/10.1029/2008JD011021

[34] Marengo, J.A., Ambrizzi, T., da Rocha, R.P., Alves, M.L., Cuadra, S.V., Valverde, M.C., Torres, R.R., Santos, D.C. and Ferraz, S.E.T. (2010) Future Change of Climate in South America in the Late Twenty-First Century: Intercomparison of Scenarios from Three Regional Climate Models. Climate Dynamics, 35, 1073-1097. http://dx.doi.org/10.1007/s00382-009-0721-6

[35] Meehl, G.A., Covey, C., Delworth, T., Latif, M., McAvaney, B., Mitchell, J.F.B., Stouffer, R.J. and Taylor, K.E. (2007) The WCRP CMIP3 Multimodel Data Set: A New Era in Climate Change Research. Bulletin of the American Meteorological Society, 88, 1383-1394. http://dx.doi.org/10.1175/BAMS-88-9-1383

[36] Jungclaus, J.H., Botzet, M., Haak, H., Keenlyside, N., Luo, J.J., Latif, M., Marotzke, J., Mikolajewicz, U. and Roeck- 
ner, E. (2006) Ocean Circulation and Tropical Variability in the Coupled Model ECHAM5/MPI-OM. Journal of Climate, 19, 3952-3972. http://dx.doi.org/10.1175/JCLI3827.1

[37] van Oldenborgh, G.J., Philip, S.Y. and Collins, M. (2005) El Niño in a Changing Climate: A Multi-Model Study. Ocean Science, 1, 81-95. http://dx.doi.org/10.5194/os-1-81-2005

[38] Nakicenovic, N., Alcamo, J., Davis, G., de Vries, B., Fenhann, J., Gaffin, S., et al. (2000) Special Report on Emissions Scenarios. Intergovernmental Panel on Climate Change Tech. Rep., 570. 
Scientific Research Publishing (SCIRP) is one of the largest Open Access journal publishers. It is currently publishing more than 200 open access, online, peer-reviewed journals covering a wide range of academic disciplines. SCIRP serves the worldwide academic communities and contributes to the progress and application of science with its publication.

Other selected journals from SCIRP are listed as below. Submit your manuscript to us via either submit@scirp.org or Online Submission Portal.
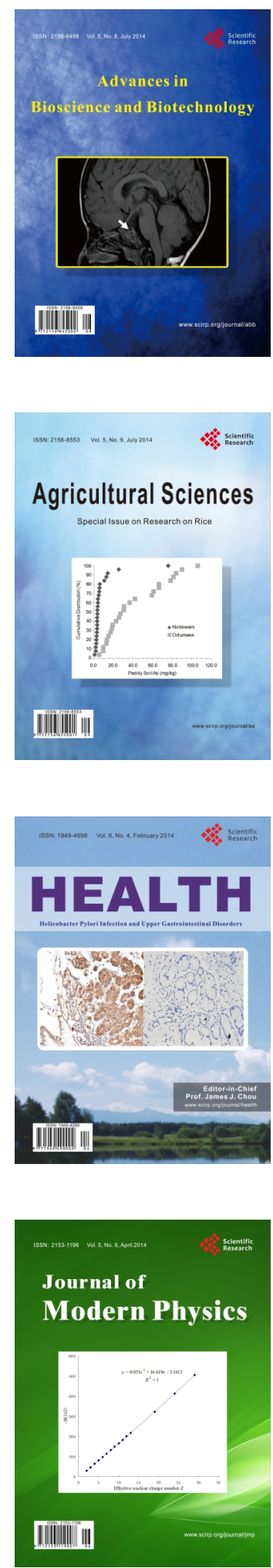
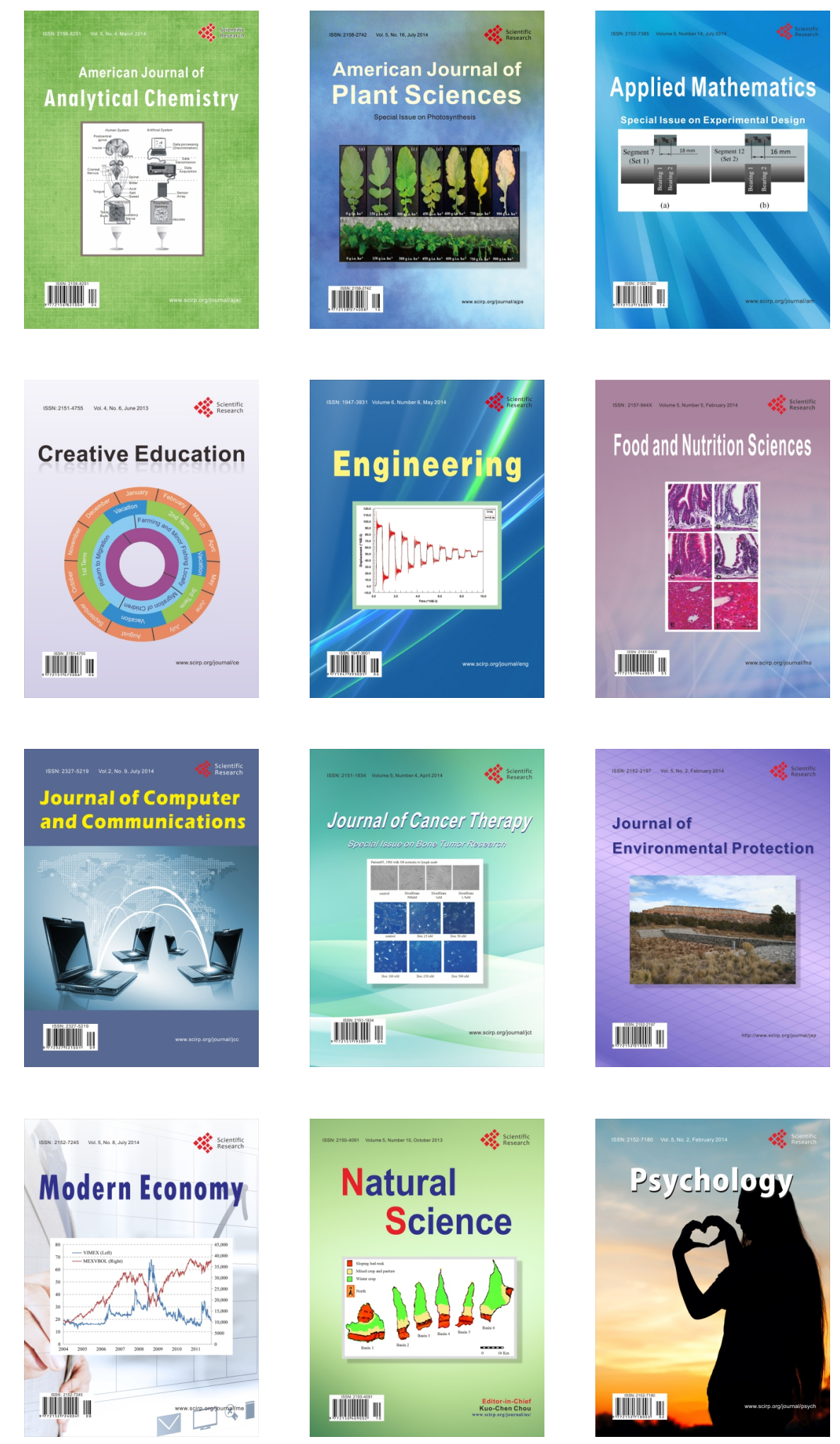